\title{
Rozwiązania Lean Management w placówkach ochrony zdrowia na świecie. Case study: wdrożenie metod Lean Management w Regionalnym Centrum Nefrologii w Szczecinku
}

http://dx.doi.org/10.18778/8142-085-3.04

Izabela Preś

Inżynier, Wydział Ekonomii, Uniwersytet Ekonomiczny w Katowicach

Maciej Dudek

Student, Wydział Zarządzania, Uniwersytet Ekonomiczny w Katowicach

\section{Lean Healthcare jako innowacyjne podejście do logistyki ośrodków ochrony zdrowia}

\subsection{Dlaczego Lean Management w ośrodkach ochrony zdrowia?}

Twórca koncepcji Lean Management, japoński inżynier Taiichi Ohno, powiedział, że wszelkie zmiany w przedsiębiorstwach zaczynają się od zaistnienia potrzeby ${ }^{1}$. W obecnych czasach potrzeba zastosowania koncepcji Lean Management w ośrodkach ochrony zdrowia podyktowana jest licznymi problemami, z którymi boryka się dzisiejsza ochrona zdrowia na całym świecie. Długie kolejki oczekujących na leczenie pacjentów, wysokie ryzyko podczas leczenia, niemożność pomieszczenia wszystkich pacjentów przez istniejące placówki to jedne $\mathrm{z}$ wielu przykładów problemów, którym należy stawić czoła, aby efektywnie zarządzać służbą ochrony zdrowia. Efektywna ochrona zdrowia to nie tylko światowej klasy lekarze, najbardziej innowacyjne rozwiązania technologiczne, ale przede wszystkim odpowiednie wykorzystywanie posiadanych zasobów poprzez optymalne zarządzanie organizacją procesów.

1 https://books.google.pl/books?id=m_vRBQAAQBAJ\&pg=PA1\&dq=lean+hospitals+mark+gr aban\&hl=pl\&source=gbs_toc_r\&cad=4\#v=onepage \&q=lean $\% 20$ hospitals $\% 20$ mark $\% 20$ graban\&f=false/ [dostęp 26.04. 2016], s. 4. 
Lean Healthcare to filozofia, w której najważniejsi są ludzie, narzędzia zaś są jej dopełnieniem. Innymi słowy „jest to sposób zarządzania jednostkami służby zdrowia oparty na zasadach Lean Management. Kluczowymi celami zarządzania według zasad Lean Healthcare jest zadowolenie pacjentów (klientów), które ma bezpośrednio przekładać się na zadowolenie udziałowców (poprawę wyników finansowych) i ciągły rozwój jednostki”2. Lean Healthcare pozwala zwiększyć efektywność procesów poprzez zwiększenie bezpieczeństwa pacjenta oraz zmniejszenie liczby bądź całkowite wyeliminowanie błędów i skrócenie długiego czasu oczekiwania na usługi zdrowotne. Co więcej, Lean Healthcare pozwala także usprawnić pracę lekarzy poprzez redukcję wąskich gardeł $\mathrm{w}$ procesach związanych $\mathrm{z}$ leczeniem pacjenta. Współpraca pracowników, zastosowanie odpowiednich narzędzi oraz integracja procesów w placówkach ochrony zdrowia umożliwiają pełne zastosowanie koncepcji Lean Management $w$ tak rozległych organizacjach.

\subsection{Początki Lean Healthcare na świecie}

Pierwsze próby wykorzystania idei Lean Manufacturing i Lean Management w ośrodkach ochrony zdrowia miały miejsce w Stanach Zjednoczonych w latach 90. XX w. W 1996 r. Szpital Seattle Children's zlokalizowany w Waszyngtonie postanowił spróbować zarządzania swoimi procesami poprzez wykorzystanie narzędzi Lean. Wdrożenie koncepcji pozwoliło placówce zaoszczędzić 180 tys. dolarów na opłaty związane $\mathrm{z}$ utrzymaniem szpitala. Jedna $\mathrm{z}$ najsłynniejszych publikacji książkowych dotyczących wykorzystania narzędzi Lean Management, zatytułowana Lean Hospitals, napisana przez amerykańskiego naukowca Marka Grabana, przedstawia liczne przykłady pozytywnych efektów płynących z zastosowania Lean Management w ośrodkach ochrony zdrowia. W placówce Avera Mc Kennan nastąpiło zredukowanie czasu pobytu pacjentów o 29\%, z kolei w szpitalu ThedaCare doszło do zmniejszenia czasu oczekiwania na zabieg ortopedyczny z 14 tygodni do 31 godzin. Wyniki te są niezwykle zaskakujące, ale jednocześnie oddają prawdziwe możliwości i potencjał, jaki wnosi Lean Healthcare.

\subsection{Lean Healthcare w Polsce. Potrzeba rewolucji w ośrodkach zdrowia}

W roku 2007 polski Trybunał Konstytucyjny wydał orzeczenie o nieograniczonej egzekucji komorniczej szpitalnych zadłużeń, co doprowadziło do bankructwa wiele placówek w Polsce ${ }^{3}$. W 2014 r. szpitale w naszym kraju odnotowały aż 10 mld

2 http://www.staworzynski.com/artykuly/lean-healthcare/ [dostęp 26.04. 2016].

3 http://lean.org.pl/lean-healthcare/ [dostęp 26.04. 2016]. 
złotych zadłużenia ${ }^{4}$. Wśród pracowników różnych ośrodków zdrowia wystąpiła panika, ponieważ zarządy często decydowały się na cięcie kosztów poprzez zwalnianie pracowników bądź ograniczanie zakupu niezbędnych nowych rozwiązań technologicznych potrzebnych do leczenia pacjentów. „Cięcie kosztów” przez ośrodki ochrony zdrowia to jedna $\mathrm{z}$ najpowszechniej stosowanych metod na poradzenie sobie z problemami. Niestety, powoduje ogromne niedogodności dla pacjentów, którzy w rezultacie muszą dłużej oczekiwać na leczenie, a to z kolei przyczynia się do zwiększenia współczynnika zachorowań, a także śmiertelności w kraju.

Potrzeba zmiany w sposobie zarządzania ochroną zdrowia w Polsce jest ogromna. Lean Healthcare pozwala na rewolucyjne spojrzenie na ochronę zdrowia poprzez odpowiednią analizę procesów zachodzących wokół pacjenta. Amerykański naukowiec, Ian Glenday stwierdził, iż „50\% wszystkich pacjentów zgłasza się ze schorzeniami, które wymagają przeprowadzenia zaledwie kilku typów procedur medycznych (dokładnie $5 \%$ ze wszystkich przeprowadzanych w danej placówce)" ${ }^{\prime 5}$. Oznacza to, że w służbie zdrowia na całym świecie, a także w Polsce, brak odpowiedniej organizacji placówek. Odpowiednia organizacja może przynieść dużo pozytywnych efektów w odniesieniu do będącego w dyspozycji budżetu. Bardzo ważne jest, aby polska ochrona zdrowia zauważyła potencjał, jaki tkwi w zastosowaniu japońskiej metody zarządzania procesami. Jest to jednak niezwykle trudne, ponieważ metoda ta stanowi nową, nieznaną dotąd powszechnie w naszym kraju koncepcję.

\section{Case study: wdrożenie metod Lean Management w Centrum Ustug Medycznych DIALIZA Sp. z o.o. ${ }^{6}$}

\subsection{Centrum Ustug Medycznych DIALIZA Sp. z 0.0.}

Centrum Usług Medycznych DIALIZA to jedna z pierwszych w Polsce niepublicznych stacji dializ. Pierwsza placówka powstała w Kostrzynie nad Odrą. Z kolei omawiana jednostka - Regionalne Centrum Nefrologii - to mały szpital specjalizujący się w leczeniu chorób nerek i cukrzycy. W placówce tej znajduje się stacja dializ, poradnia

4 http://www.forbes.pl/dlaczego-polska-sluzba-zdrowia-nie- dziala,artykuly,192871,1,1.html\# [dostęp 26.04. 2016].

5 http://lean.org.pl/lean-healthcare/ [dostęp 26.04. 2016].

6 Dane do studium zostały pozyskane od inżyniera optymalizacji procesów w ochronie zdrowia Katarzyny Złotowskiej, pracownika CUM DIALIZA Sp. z o.o. 
nefrologiczna, poradnia diabetologiczna, oddział nefrologiczno-internistyczny. Centrum zajmuje się pacjentami z przewlekłą chorobą nerek7. W 2015 r. Centrum Usług Medycznych DIALIZA zajęło drugie miejsce w konkursie na najlepsze wdrożenie narzędzi Lean Management w firmach usługowych w Polsce. Projekt wdrożenia został zatytułowany „Wdrożenie zarządzania wizualnego w Centrum Usług Medycznych DIALIZA dla zwiększenia bezpieczeństwa pacjenta, poprawy procesów i organizacji materiałów i urząazeń medycznych". Warto zaznaczyć, że jest to jedno z pierwszych w Polsce wdrożeń metod Lean Management w sektorze usług medycznych. Autorkami projektu są Katarzyna Złotowska oraz Anna Wruk-Złotowska.

Regionalne Centrum Nefrologii, jako jednostka innowacyjna, z wykwalifikowanym personelem medycznym, kilka lat temu zdecydowało się na zwiększenie poziomu bezpieczeństwa procesów klinicznych. Tym samym wdrożyło jako jedno z pierwszych w Polsce nieznany w kraju system zarządzania jakością Usługi sektora ochrony zdrowia EN 15224: 2013 (europejski standard wspierający zarządzanie jakością w usługach medycznych, procesach klinicznych i zarządzaniu ryzykiem). Wiedza na temat narzędzi i metod szczupłego zarządzania w sektorze usług zdrowotnych w Polsce jest znikoma. Być może dlatego mamy tak wiele problemów w obszarach, które aż proszą się o proste i znane rozwiązania. Niestety, specyfika branży medycznej tworzy mentalną barierę. Zasłanianie się profesjonalizmem i indywidualizmem oraz podmiotowością pacjenta jest standardem. Trudności i ograniczenia oczywiście istnieją, jednak nie tam, gdzie sugerują „przeciwnicy” tej metody. Oczywiście, nie są to świadomi przeciwnicy, oni nie sprzeciwiają się samej metodzie, tylko wdrażaniu metod stosowanych w systemach produkcyjnych. Niekiedy takie porównanie niweluje próby wykorzystania narzędzi Lean Management. Aby tego uniknąć, w Regionalnym Centrum Nefrologii wdrażano pierwsze narzędzia w obszarach, które wymagały działań korygujących, naprawczych, w których pojawiały się błędy medyczne lub zdarzenia niepożądane w opiece szpitalnej, biorąc pod uwagę pokontrolne uwagi NFZ.

\subsection{Cele wdrożenia metod Lean Management}

Placówka na początku realizacji procesu wdrażania metod Lean Management wyznaczyła sobie szereg celów, które pragnęła osiągnąć. Do głównych celów wdrożenia zaliczono: podwyższenie poziomu bezpieczeństwa procesów klinicznych, wdrożenie i utrzymanie systemu zarządzania jakością Usługi sektora ochrony zdrowia EN 15224: 2013 (norma zapewniająca świadczenie usług medycznych na porównywalnym poziomie z innymi krajami europejskimi, skupiająca się na orientacji na pacjenta), prowadzenie działań mających na celu korygowanie i zapobieganie występowaniu błędów medycznych w procesach realizowanych $\mathrm{w}$ pla-

7 http://www.dializa.com.pl/pl/o-nas/kim- jestesmy.html [dostęp 25.04. 2016]. 
cówce oraz zdarzeniom niepożądanym w funkcjonowaniu Centrum DIALIZA. Ponadto dążono do lepszego poznania zachodzących procesów i ich mapowania oraz propagowania wiedzy z zakresu znajomości narzędzi Lean Management i możliwości ich zastosowania w placówkach ochrony zdrowia w Polsce. Jest to grupa celów, które zostały wyznaczone przez zespół projektowy. Po wdrożeniu metod Lean Management nastąpiła weryfikacja poziomu ich realizacji oraz podsumowanie niezałożonych wcześniej efektów wdrożenia, które mogą wystąpić.

\subsection{Etapy wdrożenia}

Każde wdrożenie narzędzi Lean Management, nie tylko w placówkach ochrony zdrowia, ale także w innych przedsiębiorstwach usługowych oraz produkcyjnych, składa się z szeregu następujących kolejno po sobie etapów. Nie inaczej było w opisywanym przypadku. Cały projekt zainicjowało stworzenie mapy procesów realizowanych w jednostce i dokonanie wyboru tych (z procesów głównych), które będą usprawniane w kolejnych etapach. Kolejny krok obejmował dobranie zespołu ludzi - pracowników, którzy będą zaangażowani w projekt. Do grupy włączono osoby reprezentujące wszystkie szczeble organizacji. W zespole znalazły się pielęgniarki, lekarze, pracownik administracji, salowa, kierownictwo placówki oraz inżynier ds. optymalizacji procesów i ciągłego doskonalenia. W kolejnym etapie osoby tworzące zespół zostały przeszkolone w zakresie podstaw metodologii Lean Management. Istotne było również przedstawienie celu wprowadzania narzędzi Lean Management, co miało wpływać na zaangażowanie i motywację pracowników. Następnie wybrano metody, które będą użyte do implementacji (zostaną one przedstawione w kolejnym rozdziale). Z kolei nastąpił etap wdrożenia wybranych metod. Wdrożenie to będzie w ostatnim etapie walidowane pod kątem realizacji założonych celów.

\section{Narzędzia Lean Healthcare wdrożone w placówce Centrum Usług Medycznych DIALIZA Sp. z 0.0.}

\subsection{Różnorodność narzędzi wykorzystanych do wdrożenia Lean Healthcare}

Aby zrealizować cele związane z adaptacją założeń Lean Healthcare, podjęto decyzje dotyczące wyboru narzędzi i technik, które mogą usprawnić procesy zachodzące w placówce. Dobór narzędzi i technik był różnorodny, zastosowano aż 9 rozwiązań: 
- 5S,

- Kanban,

- A3,

- 5why,

- PFD - flowchart,

- VSM,

- POKA YOKE,

- FMEA,

- JIDOKA.

$\mathrm{W}$ tym rozdziale zostanie opisanych kilka $\mathrm{z}$ wymienionych technik w celu dogłębnego przeanalizowanie sposobu wykorzystania tych narzędzi i technik w placówce DIALIZA Sp. z o.o.

\subsubsection{VSM}

Narzędzie, które pozwoliło na dobre rozpoznanie sytuacji panującej w organizacji procesów w placówce DIALIZA, to mapowanie strumienia wartości (VSM). Mapowanie pozwala na zilustrowanie wszystkich procesów w sposób dostępny dla osób zaangażowanych w ich realizację. Zawiera w sobie chronologiczny opis wszystkich zachodzących procesów, z uwzględnieniem czasów ich trwania i liczby osób zaangażowanych, oraz sposób przepływu informacji czy też zasobów pomiędzy kolejnymi procesami. W celu użycia mapowania do zoptymalizowania procesów tworzy się dwie mapy: mapę stanu obecnego oraz mapę stanu przyszłego, gdzie nanoszone są zmiany, które powodują zwiększenie efektywności realizacji procesu.

Analizie poddano kilka różnorodnych procesów związanych z leczeniem pacjenta z myślą o zoptymalizowaniu tych procesów, m.in:

- proces hemodializy,

- proces hospitalizacji w oddziale nefrologicznym,

- proces leczenia wtórnej nadczynności przytarczyc,

- proces leczenia niedokrwistości w dializie.

Mapowanie składało się z kilku etapów, w celu poprawnego stworzenia mapy strumieni wartości:

1. Określenie granic procesu (początek i koniec).

2. Określenie czynności zachodzących w procesie, tj. dodających wartość, niedodających wartości procesowi oraz czynności niedodających wartości procesowi, aczkolwiek niezbędnych do zaistnienia.

3. Określenie wykonawców czynności i zasobów potrzebnych do ich realizacji.

4. Rozrysowanie procesu na flow diagram. Flow diagram jest to graficzne przedstawienie procesu poprzez użycie odpowiednich kształtów geometrycznych umożliwiających zdefiniowanie czynności pod kątem podejmowania decyzji w danej sytuacji, która może zaistnieć podczas realizowania procesu.

5. Pomiar czasu trwania poszczególnych czynności zachodzących w procesie.

6. Analiza czasu trwania poszczególnych czynności. 

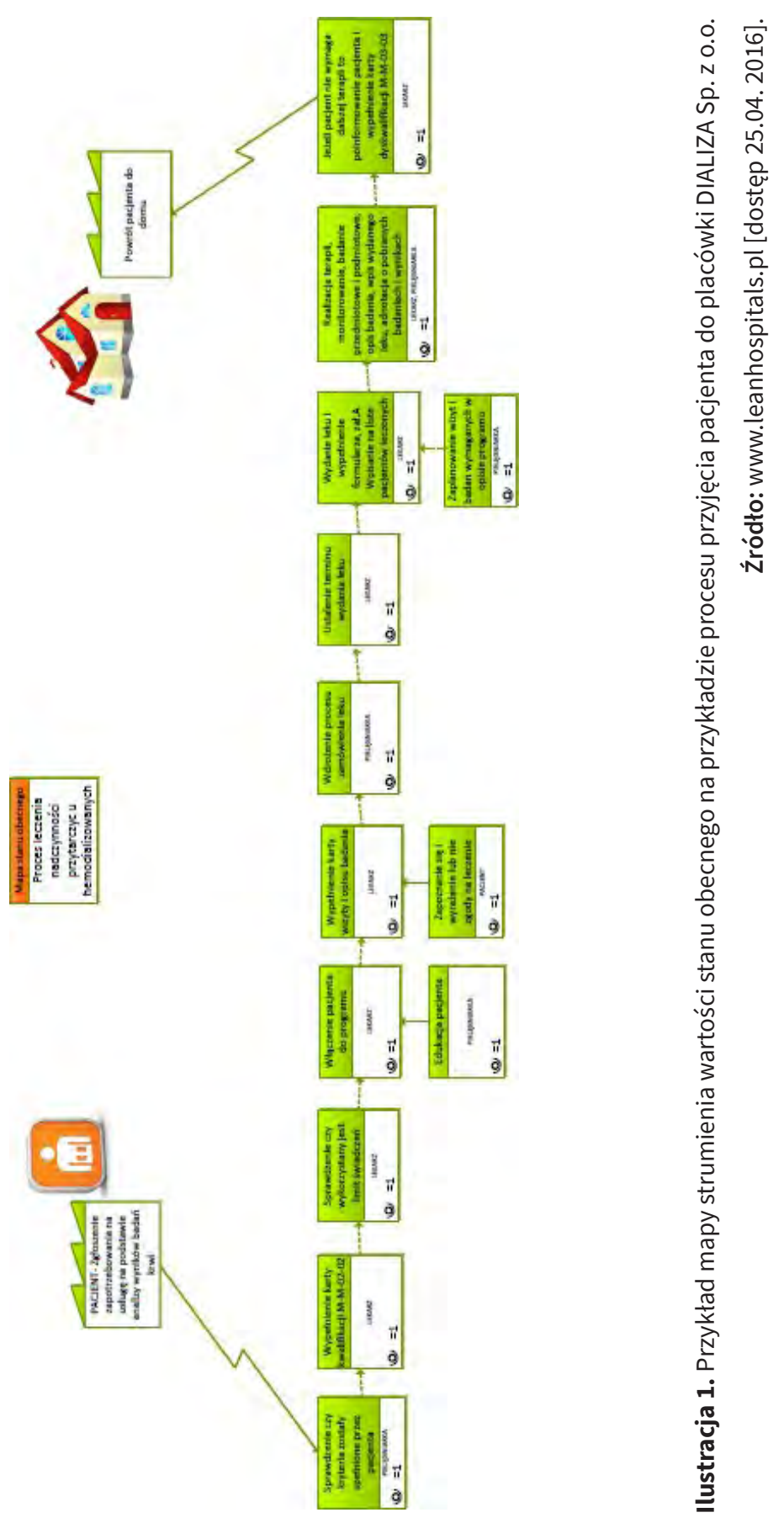
7. Wysunięcie wniosków i stworzenie mapy stanu przyszłego umożliwiającego reorganizację procesu w celu jego uszczuplenia.

8. Ciągłe doskonalenie procesów (eliminowanie marnotrawstwa).

\subsubsection{Metoda $5 S$}

Ze względu na bezpieczeństwo pacjenta i konieczność uporządkowania miejsca pracy bardzo ważne jest w szpitalach dbanie o czystość i higienę. Lean Healthcare posiada rozwiązania, które odgrywają ogromną rolę w takiej organizacji stanowiska pracy, dzięki której łatwiej będzie nam zauważyć miejsca, w których występuje problem. Metoda $5 \mathrm{~S}$ wywodzi się z Japonii i jest narzędziem ciągłego doskonalenia. Wykorzystywana jest $\mathrm{w}$ wielu branżach, w tym w ochronie zdrowia. $5 \mathrm{~S}$ to metoda organizacji pracy, a jej nazwa to skrót pięciu japońskich słów, które można przetłumaczyć jako: selekcja, systematyka, sprzątanie, standaryzacja oraz samodyscyplina.

Pierwszy etap, selekcja, polega na usunięciu z miejsca pracy zbędnych materiałów, przedmiotów, sprzętów, innymi słowy wszystkiego, co nie jest niezbędne do świadczenia opieki medycznej lub innych zadań wykonywanych w tym miejscu. Dzięki selekcji można utrzymać stanowisko pracy w ładzie i ułatwić sprawne wykonanie pracy. Kolejny etap, czyli systematyka, ma na celu odpowiednie zorganizowanie przestrzeni roboczej i wszystkich przedmiotów, które się w niej znajdują. Cel ten jest realizowany przez odpowiednie oznaczenie przedmiotów oraz miejsc, w których są one przechowywane. Dobrym przykładem jest wizualne oznaczenie tego miejsca poprzez tzw. tablicę cieni. Jest to metoda polegająca na umieszczeniu w miejscu składowania przedmiotu naklejki z nazwą przedmiotu, która dodatkowo często ma kształt samego przedmiotu. Pozwala to na szybką identyfikację miejsca składowania i zachowanie porządku. W trzecim etapie, sprzątaniu, niezbędne jest określenie częstotliwości sprzątania stanowisk. Najlepiej jeśli jest to element codziennych obowiązków pracowników. Nie chodzi tu jednak o samo fizyczne sprzątanie, ale również o porządkowanie przestrzeni pod względem wizualnym. Ma to na celu uporządkowanie stanowiska oraz umożliwienie identyfikacji ewentualnych braków w wyposażeniu. Następnie, w etapie standaryzacji tworzy się pewne standardy organizacji i zachowań. Następuje to m.in. poprzez tworzenie schematów, instrukcji, list kontrolnych czy standardów wizualnych. Finalnym etapem metody $5 \mathrm{~S}$ jest samodyscyplina, która polega na wypracowaniu wśród pracowników nawyków, które pomogą utrzymać zaimplementowane rozwiązania.

Sposób zarządzania $5 S$ został uznany za potencjalne rozwiązanie dla poprawy jakości rządowych usług medycznych w krajach o niskich i średnich dochodach ${ }^{8}$. Celem wdrożenia $5 S$ jest ciągłe usprawnianie procesów poprzez porządkowanie stanowisk pracy. Skuteczne wdrożenie metody $5 \mathrm{~S}$ musi się jednak wiązać z głęboką przemianą świadomości, zarówno pracowników, jak i kadry zarządzającej wszystkich szczebli.

8 http://www.globalhealthaction.net/index.php/gha/article/view/27256 [dostęp 25.04. 2016]. 


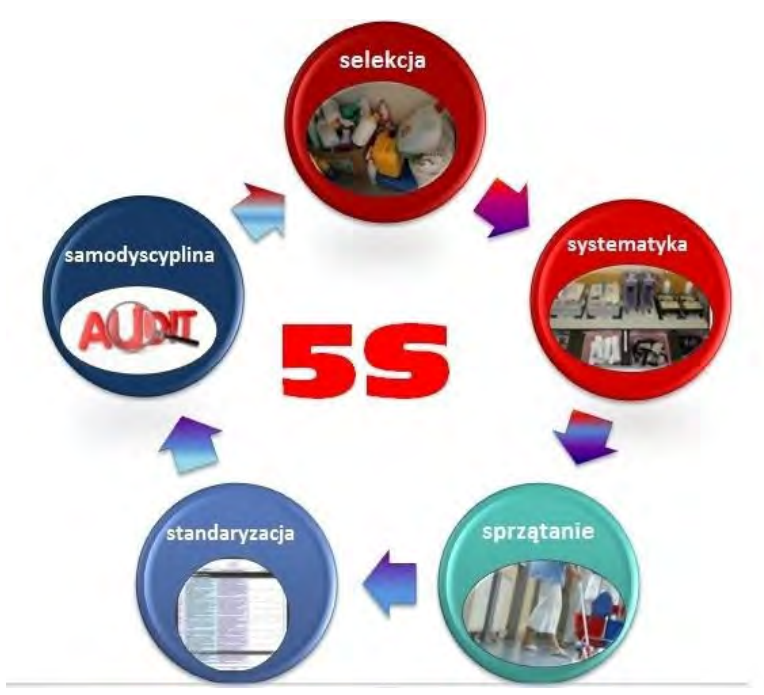

Ilustracja 2. Schemat przedstawiający istotę metody $5 \mathrm{~S}$ Źródło: www.leanhospitals.pl [dostęp 26.04.2016].

W placówce DIALIZA zaimplementowano 5S poprzez zastosowanie tzw. tablic cieni. W miejscach przeznaczonych do przetrzymywania danych narzędzi bądź przedmiotów na terenie placówki umieszczono odpowiednie naklejki ilustrujące dany przedmiot, który tam powinien zostać ulokowany. Ilustracje 3 i 4 przedstawiają niektóre z przykładów zastosowania 5S w omawianej placówce ochrony zdrowia.
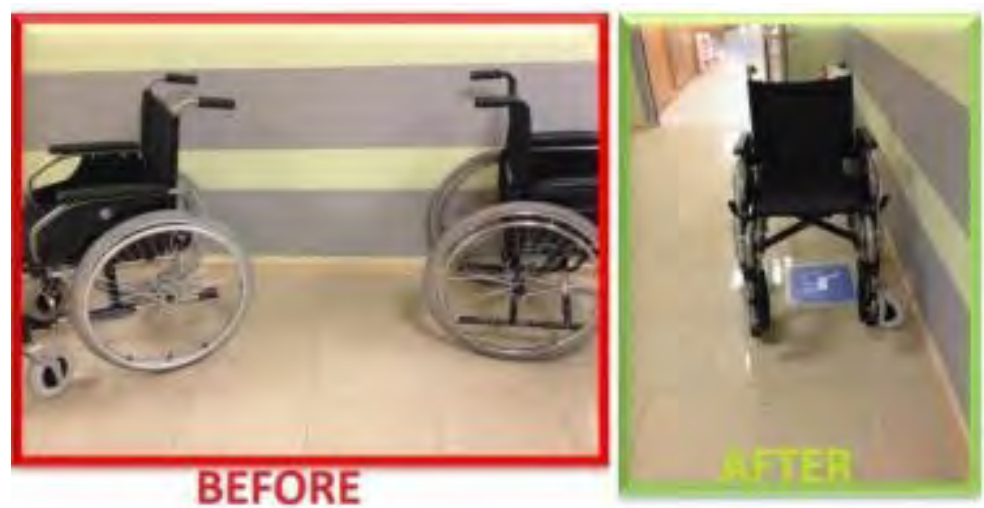

Ilustracja 3. Przykład zastosowania 5S w przypadku umiejscowienia wózków inwalidzkich Źródło: www.leanhospitals.pl [dostęp 26.04.2016]. 


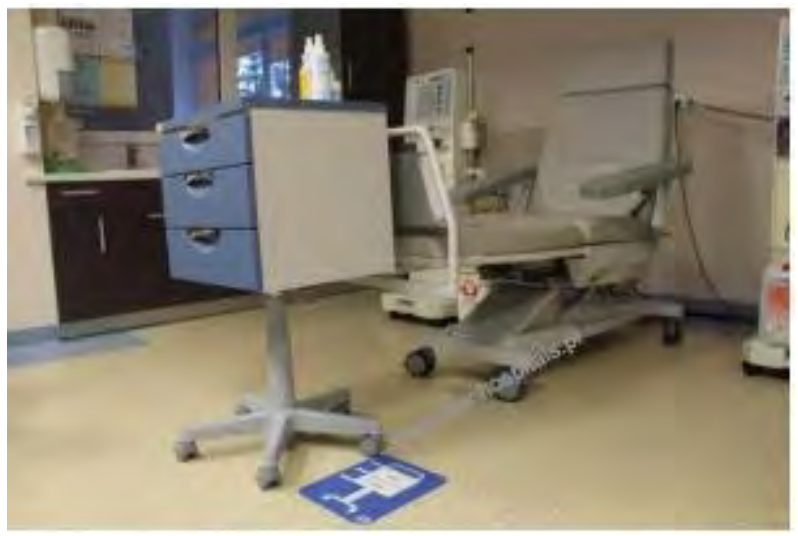

Ilustracja 4. Przykład zastosowania 5S w przypadku półki na dokumenty

Źródło: www.leanhospitals.pl [dostęp 26.04. 2016].

Ilustracje ukazują, jak duże znaczenie ma wdrożenie 5S dla możliwości lepszego zarządzania stanowiskami pracy, a zatem lepszego wykonywania obowiązków przez pracowników. Wspomniane wcześniej bezpieczeństwo pacjentów jest bardzo ważne w szpitalach, a technika uporządkowania stanowisk pracy ma w tym ogromny wkład.

\subsubsection{System kart Kanban}

System kart Kanban stanowi sposób na zarządzanie logistyką na terenie placówek ochrony zdrowia. Utrzymywanie odpowiedniej ilości zapasów narzędzi i przedmiotów niezbędnych do realizacji procesów leczenia pacjentów jest bardzo istotne. Wobec tego koncepcja Lean Healthcare posiada rozwiązanie umożliwiające utrzymanie optymalnych ilości zapasów przy stanowiskach pracy bądź na terenie magazynu placówki ochrony zdrowia.

Na terenie Centrum DIALIZA zaprojektowano karty Kanban, które zgodnie $\mathrm{z}$ teorią mają uruchamiać zapotrzebowanie na dany przedmiot $\mathrm{w}$ momencie zaistnienia popytu. Ideą zastosowania kart Kanban jest „ssanie” popytu ze strony klienta, a w przypadku sfery ochrony zdrowia - pacjenta zgłaszającego zapotrzebowanie na daną usługę zdrowotną.

Ilustracja 5 przedstawia przykładową kartę Kanban, która służy do zarządzania strzykawkami. Karta posiada krótkie, aczkolwiek konkretne hasło, przekazujące wiadomość osobie zaangażowanej w zarządzanie danym zapasem: „Jak mnie widzisz, zamów mnie". Tak prosty komunikat umożliwia łatwe rozumienie sensu posługiwania się tą kartą. Ponadto karta Kanban zawiera informacje na temat magazynu, na terenie którego znajduje się dany przedmiot. Czy będzie to magazyn materiałów jednorazowych czy np. magazyn leków. Co więcej, informuje o nazwie 


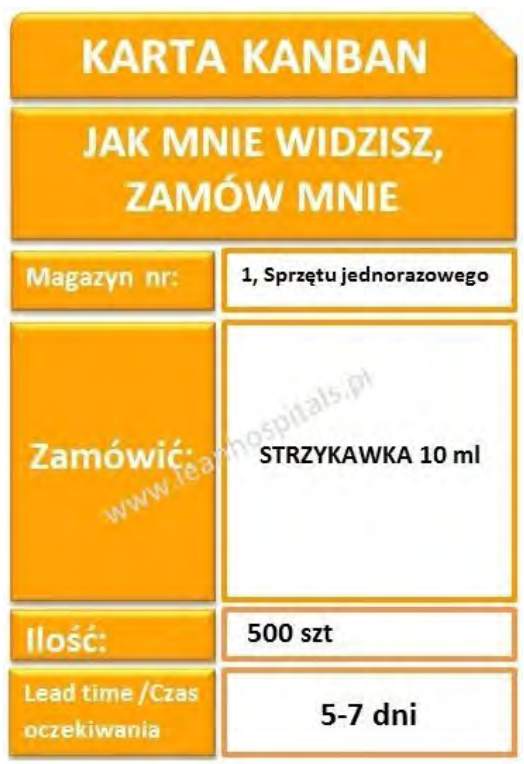

Ilustracja 5. Przykład karty Kanban stosowanej na terenie placówki DIALIZA Sp. z o.o.

Źródto: www.Leanhospitals.pl [dostęp 26.04. 2016].

danego przedmiotu oraz ilości niezbędnej do uzupełnienia. W celu zachowania optymalnego poziomu zapasu bezpieczeństwa obliczono odpowiedni czas realizacji zamówienia. Utrzymanie optymalnych zapasów materiałów na terenie każdej placówki ochrony zdrowia jest kwestią kluczową w odniesieniu do leczenia pacjenta i jego bezpieczeństwa, ale także służy optymalizacji kosztów utrzymania zapasów przez szpital. Dzięki temu ilość zapasów zmniejszyła się.

\subsubsection{Metoda 5 why ( 5 x dlaczego)}

Kolejnym narzędziem, które zostało wykorzystane w trakcie realizacji projektu, jest metoda 5 why. Ma ona podobny cel jak diagram Ishikawy, który w sposób wizualny przedstawia przyczyny problemów i wskazuje na przyczynę źródłową. W metodzie 5 why do źródła problemu dochodzi się poprzez wielokrotne zadawanie pytania „dlaczego?”. Zadaje się je tak długo, aż dotrze się do głównego problemu. Dotarcie pozwala podjąć odpowiednie kroki w celu wyeliminowania problemu i uniknięcia jego ponownego wystąpienia9.

Narzędzie to wykorzystuje się do analizy problemów, które występują w codziennych sytuacjach bezpośrednio na sali dializ oraz w poradniach na oddziale.

9 http://www.toyota-global.com/company/toyota_traditions/quality/mar_apr_2006.htm 


\subsection{Efekty wdrożenia}

Dzięki wprowadzeniu szeregu rozwiązań zaczerpniętych z narzędzi Lean Management w Centrum Usług Medycznych DIALIZA udało się osiągnąć bardzo dobre rezultaty. Zarówno pod względem organizacji pracy i efektywności procesów, jak i satysfakcji pacjentów. Imponującym wynikiem jest zredukowanie występowania ryzyka klinicznego niemal o $90 \% \mathrm{w}$ porównaniu ze stanem początkowym. Z kolei poziom zapasów w jednostce zredukowano o $30 \%$. O połowę zmniejszyła się liczba uszkodzeń sprzętu. Patrząc na zawiłe procesy zachodzące w Centrum, imponującym wynikiem jest także ograniczenie nadprocesowości o 50\%. Zostało to osiągnięte poprzez zmniejszenie liczby kroków niezbędnych do wykonania określonych procesów. Wymienione rezultaty pozwoliły na zaoszczędzenie nie tylko czasu. Dodatkowym efektem było również uzyskanie oszczędności finansowych. Jest to szczególnie dobrze widoczne na przykładzie nakładów finansowych ponoszonych na środki czyszczące. Po wprowadzeniu szczupłych procesów i szczupłego zarządzania wydatki te zmniejszyły się aż o $40 \%$. W wyniku wprowadzonych usprawnień uzyskano oszczędności rzędu $78,44 \%$ w porównaniu do wydatków poniesionych rok wcześniej $\mathrm{w}$ procesie magazynowania, utrzymania porządku i w realizacji procesów głównych. Głównym celem zastosowania Lean Healthcare w Regionalnym Centrum Nefrologii było zwiększenie bezpieczeństwa procesów klinicznych, a co za tym idzie zwiększenie bezpieczeństwa pacjenta. Dzięki filozofii Lean Healthcare personel medyczny może więcej czasu przeznaczyć na bezpośredni kontakt i opiekę nad pacjentem.

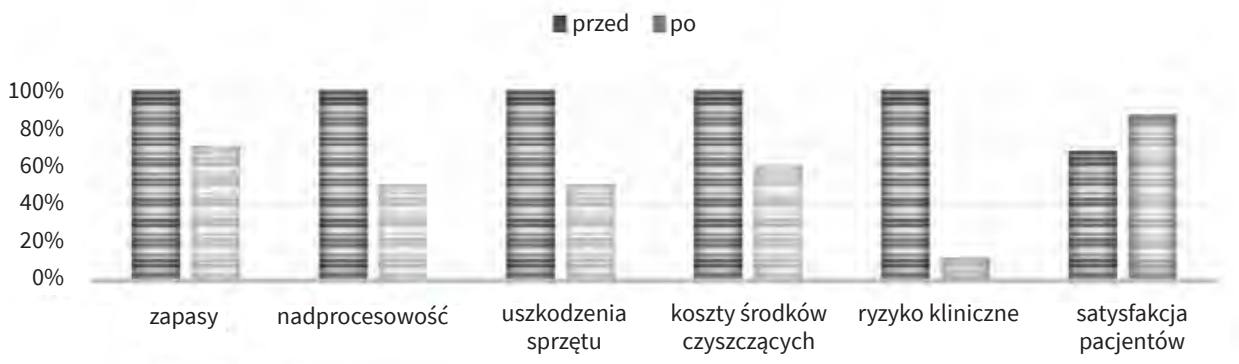

Wykres 1. Efekty wdrożenia Lean Healthcare

Źródło: opracowanie własne na podstawie leanhospitals.pl [dostęp 26.04.2016].

Podstawowym celem wprowadzania filozofii Lean Management w szpitalach, przychodniach i innych podmiotach medycznych jest zapewnienie sprawniejszej, bezpieczniejszej i stojącej na wyższym poziomie opieki nad pacjentami. Jednak spoglądając na doświadczenia szpitali amerykańskich, należy zauważyć także 
niebagatelne korzyści finansowe. Mimo że za wprowadzaniem narzędzi Lean Management nie stoi bezpośrednio chęć uzyskania korzyści finansowych, należy spojrzeć na to i z tej perspektywy. Uzyskane oszczędności finansowe można przeznaczyć na rozwój placówek, a w rezultacie na zwiększenie jakości świadczonych w nich usług. Takie właśnie korzyści osiągnęło Centrum w Szczecinku.

\section{Podsumowanie}

Odpowiadając na pytanie, dlaczego menedżerowie ochrony zdrowia zainteresowali się technikami Lean Management, warto zwrócić uwagę, że stosując dość proste i zazwyczaj stosunkowo tanie narzędzia, można wyeliminować straty czasowe i finansowe (eliminując marnotrawstwo - jap. Muda). Do głównych zalet tej metody należy zaliczyć zwiększenie bezpieczeństwa pacjentów i pracowników, uproszczenie procesów klinicznych, skrócenie czasu pobytu pacjentów w placówce medycznej, ułatwienie pracy personelowi medycznemu, zmniejszenie kosztów świadczenia usług medycznych i funkcjonowania placówek ochrony zdrowia. Stosowanie narzędzi szczupłego zarządzania pozwala na lepszą współpracę zespołu medycznego. Poszczególne narzędzia można stosować do wybranych procesów, niekoniecznie kompleksowo.

Stosowanie metod szczupłego zarządzania przynosi zatem korzyści dwustronne, bezpośrednio usprawnia działanie placówek, jak i umożliwia ich dalsze doskonalenie poprzez zapewnienie dodatkowych środków finansowych. To sprawia, że bezpieczeństwo procesów klinicznych ujmujemy od aspektu zatrudnienia profesjonalnego zespołu, wypracowania dobrych standardów dla ich realizacji, poprzez racjonalne gospodarowanie zasobami i niwelowanie zagrożeń, do poprawy efektywności ekonomicznej i braku błędów medycznych, co pozwala funkcjonować na rynku przez wiele lat.

\section{Bibliografia}

http://www.dializa.com.pl/pl/o-nas/kim- jestesmy.html http://www.forbes.pl/dlaczego-polska-sluzba-zdrowia-nie-dziala,artykuly,192871,1,1.html\# http://www.globalhealthaction.net/index.php/gha/article/view/27256 http://lean.org.pl/lean-healthcare/ 
http://www.staworzynski.com/artykuly/lean-healthcare

http://www.toyota-global.com/company/toyota_traditions/quality/mar_apr_2006.html

http://www.tuv.com/pl/poland/uslugi/systemy_zarzdzania/medycyna_opieka_zdrowotna/

din_en_15224_pl/din_en_15224.html

https://books.google.pl/books?id=m_vRBQAAQBAJ\&pg=PA1\&dq=lean+hospitals+mark+grab an\&hl=pl\&source=gbs_toc_r\&cad=4\#v=onepage \&q=lean $\% 20$ hospitals $\% 20$ mark\%20grab an\&f=false

https://www.leanhospitals.pl 